\title{
Selected Physicochemical Properties of the Soils Under Different Land Uses in Some Areas of Ethiopia
}

\author{
Araba Jemal \\ Wollega University, Faculty of Natural and Environmental Sciences, Department of Soil Resource and \\ Watershed Management, P.O. Box.395 Nekemte, Ethiopia
}

\begin{abstract}
Agriculture is the primary source of income for most developing countries, including Ethiopia. However, Ethiopian agriculture is under risk due to unwise use of land resources and changes in land use. In Ethiopia, land use changes such as conversion of natural forest to farming, open grazing, and homestead land are common. These activities have resulted in the degradation of agricultural soil quality and a decrease in land productivity, resulting in low agricultural production and food insecurity in the country. As a result, long-term advantages for environmental health and economic growth are provided through sustainable management of agricultural resources such as soil. As a result, Ethiopia has recently developed an interest in assessing the quality of soil resources. Understanding the impact of agro-ecosystem change on agricultural soil quality and long-term land production requires assessing soil physicochemical parameters and their implications on soil fertility. Thus, many studies have been conducted with regards to designated physicochemical properties of the soils under different land use types. Therefore, this review papers were aimed to assess selected physicochemical properties of the soils under different land use in some areas of Ethiopia. Different studies showed that soil physicochemical properties such as Soil texture (sand, silt, clay), Bulk density, Total porosity (\%), OC, C: N ratio, TN, $\mathrm{pH}, \mathrm{CEC}$ Ava-P, and Ava $\left(\mathrm{EB}: \mathrm{K}^{+}, \mathrm{Ca}^{2+}\right.$, and $\left.\mathrm{Mg}^{2+}\right)$, Ava $\left(\mathrm{EX} ; \mathrm{Fe}^{2+}, \mathrm{Mn}^{2+}, \mathrm{Zn}^{2+}, \mathrm{Cu}^{2+}\right)$ were influenced by different land use systems. The findings of the various research revealed that the degree and direction of changes in soil attributes under various land uses reflect the long-term impact of humans on land resources, as well as the repercussions of expanding human and animal populations. In comparison to the neighboring forest and grazing area soils, the soil properties under farmed land indicated an overall trend in the direction of loss of fertility. In general, continuous cultivation has degraded greatest of the important soil physicochemical attributes of the area as compared to the uncultivated lands. Therefore, the studies have been showed that reducing the continues cultivation and the use of integrated soil fertility management could help to sustain current soil conditions and restore the country's damaged soil qualities.
\end{abstract}

Keywords: land uses, soil fertility, soil physicochemical properties

DOI: $10.7176 / \mathrm{JBAH} / 11-15-02$

Publication date:August $31^{\text {st }} 2021$

\section{INTRODUCTION}

The economy of most developing countries, such as Ethiopia, is mostly dependent on agricultural production (IFPRI, 2010). However, Ethiopian agriculture is under risk due to unwise use of land resources and changes in land use. In Ethiopia, land use changes such as conversion of natural forest to farming, open grazing, and homestead land are common. Such shifts in land use are prevalent, especially in the highlands, where population density is high and natural resources are directly impacted (Tekle and Hedlund, 2000). These activities have caused agricultural soil quality deterioration and land productivity depletion leads to low agricultural efficiency and food uncertainty in the country. Agricultural soil quality degradation in this case refers to the reduction in soil fertility due to various human activities. These human activities (fertilizer application, agricultural residue removal, land plowing, etc.) are major contributors to changes in soil physicochemical attributes in Ethiopia (Kippe, 2002). In addition, intensive and continuous land cultivation without effective management resulted in a loss in soil physical, chemical, and biological qualities, further reducing crop yields and increasing food insecurity (Habtamu et al., 2014).

Cultivation on steep and fragile soils with insufficient investments in soil conservation or vegetation cover, erratic and erosive rainfall patterns, declining use of fallow, limited recycling of dung and crop residues to the soil, limited application of external sources of plant nutrients, deforestation, and overgrazing are all factors that contribute to land degradation in Ethiopia (Belay, 2003; Hurni, 1988). As a result, governments in tropical Africa face tremendous problems in decreasing resource degradation, boosting agricultural output, reducing poverty, and ensuring food security. Thus, every effort should be made to preserve the physical, chemical, biological, and socioeconomic environment for the production of food crops, animals, wood, and other goods through the ecosystem's sustainable use.

Despite widespread recognition that land degradation is a threat to agricultural output, few studies have been conducted in the country to quantify the amount, rate (status), and processes of soil physicochemical depletion under various land uses and management techniques (Elias, 2002). Among these, Habtamu et al. (2014) 
and Birhanu (2016) found that converting a natural ecosystem to a crop/cultivated land ecosystem has led to in a deterioration of the soil resource base, and that most of the physicochemical properties of soils have been significantly influenced by the various land uses.

On the other hand, land use change, especially from natural ecosystems to agricultural areas in general and crop cultivation under inadequate management techniques in particular, is one of the leading drivers of soil fertility decline, followed by land degradation and low agricultural productivity (Achalu et al., 2012). Another investigation also showed that the lesser organic matter content in the cultivated land units might be owing to higher rates of OM decomposition aggravated by intensive cultivation, and also perhaps because of low rates of return of organic materials as crop residues due to a number of competing ends, such as; animal feed, fuel, construction, etc (Kedir et al., 2016). However, Kibebew and Mishra (2017) reported on the relevance of organic farming in Ethiopian agriculture and concluded that Ethiopia has tremendous organic resources, particularly in the highlands, which should be exploited for scientific use in maintaining and promoting soil health and fertility. The study by Muche et al., (2015) indicated that differences in soil physicochemical attributes were observed under the soils of selected land use types in the Northwestern Ethiopia. They further reported that variations in soil physicochemical properties could be linked to frequent tillage, crop residue harvest, the use of acid-forming fertilizers, and the conversion of forest land to other land use types, all of which lead to poor nutrient availability in the soil and, as a result, crop production limitations. According to Desta (1983), significant disparities in the micronutrient content of Ethiopian cultivated lands were also detected. While iron and manganese were found to be acceptable, zinc levels ranged from low to high, with copper being the most deficient.

The productivity of a soil is also affected by changes in land use. These manifest as changes in soil attributes such as macro and micronutrient availability, organic matter, CEC, and soil structure, among others (Aluko and Fagbenro, 2000). A periodic examination of soil fertility status is required for agricultural sustainability. This is vital for understanding elements that impose substantial limits on enhanced crop production under various land use types and for the implementation of appropriate land management strategies.

As a result, determining the effects of land use-induced changes on soil physicochemical properties and their implications for soil fertility is critical for understanding the impact of agro-ecosystem transformation on agricultural soil quality and productivity, as well as identifying appropriate and sustainable agricultural soil and land management options. Therefore, the objective of this review is to evaluate selected physicochemical properties of soils under various land uses in Ethiopia.

\section{METHODOLOGY OF REVIEW}

To the accomplishment of this work, different sources such as journals, proceedings, thesis works and annual reports linked to designated physicochemical properties in different land uses have been used.

\section{SOIL PHYSICOCHEMICAL PROPERTIES AS AFFECTED BY DIFFERENT LAND USES}

\subsection{Overview of land use change}

Changes in land use are seen as critical components and a key source of global environmental change (Turner et al., 1995; Li, 1996; Wasihun, 2015). The number, rate, and intensity of land use changes in developing countries, such as Ethiopia, are quite high. Human impacts on the land are still significant and growing (Rao and Pant, 2001). The most prevalent alteration in Ethiopian ecosystems is extensive deforestation and conversion of natural forests to agricultural areas. Destruction continued unabated, particularly in the south and south-west of the country, where the majority of the country's remaining sub-humid tropical forests may be found (Solomon et al., 2002). Its study has arisen out of efforts in most developing nations to identify, forecast, and manage ecologically detrimental land use changes such as deforestation, which has enormous ramifications for human livelihood systems.

\subsection{Impacts of Land Use Change on Soil Physical Properties}

Soil physical properties, such as structure, texture, bulk density, moisture retention characteristics, and soil aeration, have a significant impact on soil fertility and productivity. As a result of natural and anthropogenic processes, these soil physical properties vary from place to place and even within a micro level. Several physical properties of soils are influenced by land use and management. For example, many physical properties of soil alter with intensity of cultivation, instruments employed, and the type of the land under cultivation (Sanchez, 1976; Achalu et al., 2012).

\subsubsection{Soil texture}

The relative proportion of particles of various sizes in a given soil is known as soil texture. The physical and chemical qualities of soils are determined by their texture. It has an impact on water infiltration and retention, soil aeration, nutrient absorption, microbial activity, tillage, and irrigation methods (Foth, 1990; Gupta, 2004). Several studies explained that particle size distribution of the soils showed a significant difference under different land use. According to Teshome et al., (2013), the textural class of all land use categories was clay 
(Table 1), indicating that the parent material was identical. However, Clay content in the surface layer $(0-20 \mathrm{~cm})$ of the soils differed significantly between land use categories. Its content in cultivated land was much lower than in forest and grazing fields. The low clay in cultivated land's surface layers could be attributed to erosion removing clay off the surface selectively, meaning that cultivated land is more prone to erosion than nearby forest and grazing fields. Similarly, Lechisa et al., (2014) found that clay was the textural class of all land use types (Table 1), indicating that the parent material was identical. Clay content, on the other hand, varied greatly depending on the land use type. Similarly, Mamo (2011) found that cultivated land had higher clay concentration than grazing land and natural forest soils. The impacts of deforestation and farming activities are related to the higher mean clay fraction reported in cultivated land (Chikezie et al., 2009). Overall, the reason for clay content varies in surface layers of among the land use types might be due to erosion selectively removes clay from the surface, cultivated land is more vulnerable to erosion and the effects of deforestation and farming practices. Teshome et al. (2013) and Lechisa et al. (2014) found that forest land had much greater silt content than cultivated and grazing land. This implies that cultivated land is more prone to erosion than nearby woodland and grazing fields. Grazing area had a higher sand content than cultivated land, which had a lower sand content.

3.2.2. Bulk density

The mass of a unit volume of oven-dry soil is known as bulk density (BD). Soil BD varies depending on the texture, structure, and organic matter content, among other factors. Soil bulk density is highly influenced by soil management practices such as land use type and soil management practices. For example, continues cultivation rises bulk density resulting in decreasing of total porosity. Soils under cultivated land have much higher bulk density than soils under forest and grazing fields, according to Lechisa et al., (2014) and Mamo (2011). Similarly, Islam and Weil (2000) found that as the cultivation period increased, the bulk density increased significantly. The advanced bulk density under the cultivated land might be related to the intensive tillage practices which may temporarily loosen the tilled soil layer and in the long term leads to increases in bulk density. In addition, the smallest organic matter (OM) content available in the cultivated land soils also contributes to the highest bulk density. However, (Teshome et al., 2013) found that bulk density varied quantitatively very slightly between land use types (Table 1). The cause for this could be related to the study area's recent conversion of forest land to grazing and farmed lands. In general, higher bulk density under cultivated land may be attributable to extensive tillage, constant exposure of the soil surface to direct rain drop impact under fields with long periods of continuous cultivation, and the lowest organic matter (OM) content available in the cultivated area.

Table 1. Soil Physical properties influenced by different land uses

\begin{tabular}{|c|c|c|c|c|c|c|c|}
\hline \multirow{2}{*}{$\begin{array}{l}\text { Land } \\
\text { uses }\end{array}$} & \multicolumn{3}{|c|}{ Particle size distribution (\%) } & \multirow{2}{*}{$\begin{array}{l}\text { Textural } \\
\text { Class }\end{array}$} & \multirow[t]{2}{*}{$\mathrm{BD}(\mathrm{g} / \mathrm{cm} 3)$} & \multirow{2}{*}{$\begin{array}{l}\text { Studied } \\
\text { Area }\end{array}$} & \multirow[t]{2}{*}{ Authors } \\
\hline & Sand & Silt & Clay & & & & \\
\hline $\begin{array}{l}\text { Forest } \\
\text { land }\end{array}$ & 28.42 & $21.25^{\mathrm{b}}$ & $50.33^{\mathrm{a}}$ & Clay & $1.20^{\mathrm{c}}$ & $\begin{array}{l}\text { Abobo } \\
\text { Area, }\end{array}$ & $\begin{array}{l}\text { Teshome } \\
\text { et al ,2013 }\end{array}$ \\
\hline $\begin{array}{l}\text { Grazing } \\
\text { land }\end{array}$ & 29.08 & $21.75^{\mathrm{b}}$ & $49.17^{\mathrm{ab}}$ & Clay & $1.26^{\mathrm{a}}$ & $\begin{array}{l}\text { Western } \\
\text { Ethiopia }\end{array}$ & \\
\hline $\begin{array}{l}\text { Cultivated } \\
\text { land }\end{array}$ & 27.91 & $25.08^{\mathrm{a}}$ & $47.00^{\mathrm{b}}$ & Clay & $1.23^{\mathrm{b}}$ & & \\
\hline $\begin{array}{l}\text { Forest } \\
\text { land }\end{array}$ & $22.46 \pm 4.18^{\mathrm{b}}$ & $30.09 \pm 2.07^{\mathrm{a}}$ & $47.45 \pm 5.00^{\mathrm{a}}$ & Clay & $1.09 \pm 0.02^{\mathrm{c}}$ & $\begin{array}{l}\text { Gindeberet } \\
\text { District }\end{array}$ & $\begin{array}{l}\text { Lechisa et } \\
\text { al., } 2014\end{array}$ \\
\hline $\begin{array}{l}\text { Grazing } \\
\text { land }\end{array}$ & $21.16 \pm 3.85^{\mathrm{a}}$ & $19.10 \pm 1.88^{\mathrm{b}}$ & $59.74 \pm 6.69^{\mathrm{a}}$ & Clay & $1.28 \pm 0.02^{\mathrm{a}}$ & & \\
\hline $\begin{array}{l}\text { Cultivated } \\
\text { land }\end{array}$ & $25.15 \pm 2.88^{\mathrm{c}}$ & $24.93 \pm 2.97^{b}$ & $49.92 \pm 2.81^{\mathrm{a}}$ & Clay & $1.24 \pm 0.01^{\mathrm{b}}$ & & \\
\hline Forest & $32.16^{\mathrm{a}}$ & 31.17 & $36.67^{\mathrm{b}}$ & Clay & $1.02^{\mathrm{b}}$ & South & Mamo \\
\hline land & & & & loam & & Gonder, & Yalew \\
\hline $\begin{array}{l}\text { Grazing } \\
\text { land }\end{array}$ & $32.49^{\mathrm{a}}$ & 31.74 & $35.33^{\mathrm{b}}$ & $\begin{array}{l}\text { Clay } \\
\text { loam }\end{array}$ & $1.30^{\mathrm{a}}$ & $\begin{array}{l}\text { Agedit } \\
\text { Watershed }\end{array}$ & $(2011)$ \\
\hline $\begin{array}{l}\text { Cultivated } \\
\text { land }\end{array}$ & $21.16^{\mathrm{b}}$ & 28.17 & $50.67^{\mathrm{a}}$ & Clay & $1.43^{\mathrm{a}}$ & & \\
\hline
\end{tabular}

\subsubsection{Total Porosity}

Total porosity (TP) is an index of relative pore space in the soil that is calculated as the ratio of total volume of pore spaces to total volume of soil. Its value varies from 30 percent (in compacted subsoil) to more than $60 \%$ (in well-aggregated high-OM surface soils) (Brady and Weil, 2002). In the same way that BD is used to determine the degree of compaction in a soil, total porosity (TP) can be used to determine the degree of compaction in a soil. According to Mamo (2011), varied land uses in the Agedit watershed, south Gonder, have a substantial impact on total porosity. The average surface total porosity of the forest, cultivated and grazing lands were 59.09, 
45.84 and $42.53 \%$, respectively. Proportion total porosity reduced from the surface soils $(50.96 \%)$ to the subsurface soils (47.34\%). This is ascribed to the small OM contents in the subsurface horizons and the clogging up of pore spaces by clay particles translocated from the surface soil layer. Compaction due to the loading of the overlying horizons as general trend had also contributed to the decrease in soil porosity with depth. According to Wakene (2001), the lower total porosity detected in the subsurface layers of soils classified in Bako, Western Ethiopia, was caused by low OM levels and high bulk density imposed by heavy machinery for tillage activity and intensive grazing of fallow land. Similarly, (Jobira, 2018) reported that, total porosity was significantly varying among the land uses at Wuye Gose subwatershed in North shoa Oromia Region. Accordingly, the highest (57.25\%) mean TP was detected in the soils of the HL, while the lowest $(43.04 \%)$ was observed in the soils of the GL. This is similar with the result reported by Habtamu et al. (2014) implied that compaction by grazing increased BD and intern lowered TP of soil.

\subsection{Impacts of Land Use Changes on Soil Chemical Properties}

Chemical properties of the soils are the most essential among the elements that determine the soil's ability to give nutrients to plants and microbes. A chemically fertile soil contains adequate amounts of the various substances required for plant nutrition, in available forms, which is not excessively acidic or alkaline and is free from toxic agents (Hillel, 1980; Foth and Ellis, 1997). Chemical properties of soils change with change in management and land use. Variations in land use alter the condition of soil organic matter, nitrogen and other essential nutrients (Bohn et al., 2001).

3.3.1. Soil $\mathrm{pH}$

Soil reaction $(\mathrm{pH})$ is a degree of the concentration of hydrogen ions $(\mathrm{H}+)$ in solution of the soil. Soil $\mathrm{pH}$ is a useful soil quality indicator because it influences, and is influenced by so many other soil properties. Several studies showed differences in soil pH among under different land use types. According to Teshome et al (2013), there were no significant differences in soil $\mathrm{pH}$ between land use types. The $\mathrm{pH}$ ranges among the land use types were generally narrow (5.9 to 6.1). There was no application of fertilizer use in the area, which could have influenced the $\mathrm{pH}$ of the soils. However, soil $\mathrm{pH}$ was found to be significantly changed across land use types by Lechisa et al., (2014). The $\mathrm{pH}$ of the soil varies from 5.65 to 4.88 depending on the land use type. Forest land had the highest $\mathrm{pH}$ value, followed by grazing land and then cultivated land. Following Brady and Weil's (2002) classification, the soil $\mathrm{pH}$ of cultivated and grazing land may be classified as strongly acidic, whereas that of forest land could be classified as moderately acidic. The lower soil $\mathrm{pH}$ value in farmed land could be related to the depletion of basic cations during crop harvest, as well as the maximum microbial oxidation, which produces organic acids, which provide $\mathrm{H}$ ions to the soil solution, lowering the soil $\mathrm{pH}$ value. Mamo (2011) also found that land use type had a significant impact on the $\mathrm{pH}$ of the soil. The highest (5.86) and lowest (5.20) soil pH values were found under forest and cultivated fields, respectively, when considering the influence of land use (Table2). There are three key reasons for the lowest $\mathrm{pH}$ value under cultivated land. The first is the loss of baseforming cations from soil profiles beyond sample depths due to leaching and draining to streams in rapid erosion runoff. This promotes $\mathrm{Al} 3+$ and $\mathrm{H}+$ activity in the soil solution, lowering soil $\mathrm{pH}$ and increasing soil acidity. The second reason for the drop in soil $\mathrm{pH}$ is the depletion of basic cations during crop harvest, as evidenced by their reduction (Table 2). The third factor is the continued use of ammonium-based fertilizers in cereal-based cultivated areas, such as diammonium phosphate, (NH4)2HPO4, which, when oxidized by soil bacteria, creates powerful inorganic acids. These powerful acids then release $\mathrm{H}+$ ions into the soil solution, lowering the $\mathrm{pH}$.

3.3.2. Soil Organic Matter

Soil organic carbon (OC) is a metric for how much organic matter is in the soil (OM). Soil organic matter (OM) is described as any live or dead plant or animal components in the soil, and it includes a variety of organic species such as humic compounds, carbohydrates, proteins, and plant leftovers (Foth and Ellis, 1997). Changes in land usage result in changes in soil organic carbon. According to Teshome et al (2013), the soil organic matter OM content of cultivated land was much lower than that of forest and grazing fields, whereas there was no significant difference between the two (Table 2). This could occur as a result of deforestation and subsequent agriculture. Furthermore, the complete removal of crop leftovers from farmed land may have resulted in a decrease in soil organic matter. Similarly, Lechisa et al., (2014) found that soil OM concentrations differed significantly depending on the land use type (Table 2). The organic matter (OM) content of soils under cultivated and grazing land was lower than that of soils under forest land. It may be concluded that losses of forest-derived soil organic matter were not entirely balanced by organic matter input from cereal crop residues under cultivated land uses. In comparison to cultivated soils, grazing field soils have a lower level of disturbance, which appears to have resulted in an increase in organic matter content. Though the lack of such soil disturbance slows the loss of soil organic matter, export of nutrients and poor biomass recovery after grazing have both played a role in its decline when compared to observations made in forest area (Weldeamlak and Stroosnijder, 2003; Genxu et al., 2004). In addition, Mamo (2011) found that land use and soil depth had a substantial impact on soil organic matter $(\mathrm{OM})$ concentration. Soil OM concentration was highest $(3.28 \%)$ in forest land soils and lowest $(2.12 \%)$ 
in cultivated land soils. The depelition of organic substrate inputs from the farming system due to residue removal and zero crop rotation may have exacerbated the fall in soil OM content on cultivated land following deforestation and conversion to farm fields.

\subsubsection{Total Nitrogen}

Nitrogen $(\mathrm{N})$ is one of the most abundant vital nutrient elements taken up by plants, but it is also one of the most insufficient elements for crop development in the tropics (Mengel and Kirkby, 1987; Mesfin, 1998). Total soil nitrogen (TN) refers to both inorganic and organic nitrogen in the soil. According to Teshome et al. (2013), the total $\mathrm{N}$ content of all land use types was medium (Tekalign, 1991). The content of cultivated land, on the other hand, was much smaller than that of other land uses. It's possible that this is owing to the quick mineralization of SOC. Similarly, Lechisa et al., 2014 found that soil total $\mathrm{N}$ was influenced significantly across all land use types. The total $\mathrm{N}$ content of cultivated and grazing fields was medium, while the mean value of total $\mathrm{N}$ in forest land was high (0.11 percent). Cultivated land, on the other hand, has substantially lower content (0.08 percent) than the other land use groups. Because the majority of soil nitrogen is bound in organic carbon, such a result is expected. In line with this, (Yifru, 2011) found that the total $\mathrm{N}$ concentration of cultivated soils was lower than that of natural forest soils. The vegetation cover on forest land may have enhanced the soil organic matter content, resulting in an increase in soil total nitrogen concentration. The total $\mathrm{N}$ content of soils was also greatly altered by land use, according to Mamo (2011). As a result, the average total nitrogen value was highest on forest land and lowest on cultivated land. Total $\mathrm{N}$ decreased when land uses changed from natural forest to agricultural fields, accordance with OM. Generally, the soil OM and total nitrogen contents of the cultivated lands were significantly lesser as compared to that of the uncultivated lands (forest and Grazing) lands. This revealed the effect of continuous cultivation in enhancing OM oxidation and resulting in reduction of OM and total N.

3.3.4. Available Phosphorus

Phosphorus (P) is an important element that is categorized as a macronutrient due to the significant amounts of $\mathrm{P}$ that plants require. $\mathrm{P}$ uptake by plants is restricted in most natural environments, such as forests and grasslands, due to both the low total quantity of the element in the soil and the relatively poor solubility of the scant quantity that is there (Brady and Weil, 2002). Next to N, it is the most prevalent plant growth-limiting nutrient in tropical soils (Mesfin, 1996). The accessible P concentrations of soils under all land uses were typically high and extremely high. According to Teshome et al (2013), while cultivated land soils exhibited significant difference with forest and grazing areas. Crop mining, crop residue clearance, and erosion all contributed to a $33 \%$ in accessible P content between farmed and forest land. Similarly, Lechisa et al., (2014) found that while available phosphorus in cultivated and grazing fields did not change significantly, it did differ significantly in forest land. However, Mamo (2011) found that, the available phosphorus contents of the soils were significantly influenced by land use. The amount of available phosphorus in the cultivated land was significantly greater than its content in the grazing land while it was statistically at par with that of the forest land soils. The farm lands contained higher available $\mathrm{P}$ than the non-cultivated lands, which might be owing to the continuous application of $\mathrm{P}$ fertilizers in the former. Tekalign et al. (1988), Whitebread et al. (1998) and Wakene (2001) found similar results and described that the less concentration of available phosphorus in the non-cultivated lands might be due to the inherent phosphorus shortage of the soil since small or no phosphorus fertilizers are applied.

Table 2. Soil chemical properties influenced by different Land uses

\begin{tabular}{|c|c|c|c|c|c|c|c|}
\hline \multirow[b]{2}{*}{ Land uses } & \multicolumn{4}{|c|}{ Soil Chemical properties } & \multirow{2}{*}{$\begin{array}{l}\text { Studied } \\
\text { Area }\end{array}$} & \multirow{2}{*}{\multicolumn{2}{|c|}{ Authors }} \\
\hline & pH (H2O) & OM (\%) & TN (\%) & $\begin{array}{l}\text { Av.P } \\
\text { (mg/kg) }\end{array}$ & & & \\
\hline Forest land & 6.1 & $3.76^{\mathrm{a}}$ & $0.18^{\mathrm{a}}$ & $24.13^{\mathrm{a}}$ & Abobo Area, & Teshome & et \\
\hline Grazing land & 6.0 & $3.74^{\mathrm{a}}$ & $0.16^{\mathrm{a}}$ & $22.47^{\mathrm{a}}$ & Western & al., 2013 & \\
\hline Cultivated land & 5.9 & $2.52^{\mathrm{b}}$ & $0.12^{\mathrm{b}}$ & $19.24^{\mathrm{b}}$ & Ethiopia & & \\
\hline Forest land & $5.65 \pm 0.26 \mathrm{a}$ & $2.01 \pm 0.41 \mathrm{a}$ & $0.11 \pm 0.02 b$ & $4.30 \pm 0.27 b$ & Ginde beret & Lechisa & et \\
\hline Grazing land & $4.88 \pm 0.23 c$ & $1.38 \pm 1.25 b$ & $0.08 \pm 0.05 \mathrm{a}$ & $2.23 \pm 0.01 \mathrm{c}$ & District & al., 2014 & \\
\hline Cultivated land & $5.32 \pm 0.09 \mathrm{~b}$ & $1.84 \pm 0.09 \mathrm{~b}$ & $0.09 \pm 0.02 \mathrm{a}$ & $12.74 \pm 0.01 \mathrm{~b}$ & & & \\
\hline Forest land & $5.86 \mathrm{a}$ & $3.28 \mathrm{a}$ & $0.310 \mathrm{a}$ & $3.83 a$ & South & Mamo & \\
\hline Grazing land & $5.31 b$ & $2.41 \mathrm{ab}$ & $0.256 \mathrm{a}$ & $2.76 b$ & Gonder, & Yalew, & \\
\hline Cultivated land & $5.20 \mathrm{~b}$ & $2.12 b$ & $0.165 b$ & $4.40 \mathrm{a}$ & $\begin{array}{l}\text { Agedit } \\
\text { Watershed }\end{array}$ & (2011) & \\
\hline
\end{tabular}

3.2.2. Cation Exchange Capacity

The capacity of soils to absorb and exchange cations is known as cation exchange capacity (Brady and Weil, 2002). Cation exchange capacity is an important soil metric because it indicates the type of clay minerals present, the soil's ability to hold nutrients against leaching, and the fertility and environmental behavior of the soil. In general, the CEC of a soil determines its chemical activity. According to Teshome et al (2013), the cation exchange capacity of soils under all land uses was high, according to the rating by (P. Hazelton and B. Murphy, 
2007), though cultivated land differed significantly from the other land uses. The low CEC on cultivated land corresponded to the soils' low clay and organic matter content in this land use. The decline in soil CEC values in agricultural land uses was primarily attributable to lower organic matter content. Similarly, Gebeyaw (2007) found that land use had a substantial impact on the CEC values of the soils in the studied area. CEC levels were found to be highest and lowest in the forest and cultivated fields, respectively. Clay and colloidal OM both have the potential to absorb and keep positively charged ions, which is a universal reality. Soils with a lot of clay and organic matter have a lot of cation exchange capacity. Furthermore, Mamo (2011) found that land use had a substantial impact on the cation exchange capacity (CEC) values of the soils in the study area. The highest and lowest values of CEC were found under forest and cultivated lands, respectively, when considering the effects of land use (Table 3). In general, CEC values in agricultural land uses decreases, owing to a decreasing in OM content. The relative amounts and/or types of the two main colloidal components, humus and clay, govern the CEC of soil. Because organic matter has more negatively charged surfaces than clay particles, it plays an essential role in soil exchange activities. The relatively high CEC values found in forest land can be linked to the fact that soil on forest land accumulates a high percentage of organic carbon and has a greater capacity to store cations, resulting in increased potential fertility in the soil. Therefore, an increase in soil CEC is expected as the OM content of the soil improves. Deforestation, overgrazing, and the conversion of forest to cropland without sufficient management, on the other hand, exacerbates soil fertility loss in cultivated land. The current findings are consistent with those of (Achalu et al., 2012), who found the highest CEC value in forest land soils and the lowest in cultivated land soils.

3.2.3. Exchangeable Bases

$\mathrm{Ca}, \mathrm{Mg}, \mathrm{K}$, and $\mathrm{Na}$ are examples of exchangeable basic cations (EB). With a $\mathrm{pH}$ of 5.5 or above, the distribution of exchangeable basic cations in typical agricultural soil is $\mathrm{Ca}>\mathrm{Mg}>\mathrm{K}>\mathrm{Na}$ (Bohn et al., 2001; Teshome et al., 2013). According to Teshoma et al., 2013, and Gebeyew (2007), land use has a substantial impact on exchangeable bases. . Forest land exchangeable bases differed significantly from cultivated and grazing lands (Table 3). The results showed that, in contrast to grazing and cultivated areas, where basic nutrients were lost owing to grazing and harvesting, the exchangeable base contents in the forest ecosystem were well maintained due to nutrient recycling. $\mathrm{Ca}$ was the most abundant element in the exchange complex, followed by $\mathrm{Mg}, \mathrm{K}$, and $\mathrm{Na}$, indicating fruitful agricultural soils. Similarly, Mamo (2011) found that land usage had a considerable impact on the content of exchangeable calcium (Ca) and magnesium $(\mathrm{Mg})$ (Table 3). Forest land and cultivated land had the highest and lowest values of exchangeable $\mathrm{Ca}$ and $\mathrm{Mg}$, respectively. According to Singh et al. (1995) the lowest values found on cultivated land could be connected to the influence of intensive cultivation and plentiful crop harvest with little or no use of input. Land use categories have a considerable impact on exchangeable $\mathrm{K}$ and $\mathrm{Na}$ content. Exchangeable $\mathrm{K}$ and $\mathrm{Na}$ content were highest in forest land and lowest in cultivated land when considering the effects of land use (Table 3). The greatest content in the forest land was associated to its high $\mathrm{pH}$ value, which was consistent with Mesfin's (1996) findings that high K levels were found in high $\mathrm{pH}$ tropical soils. Deforestation, leaching, restricted dung and crop residue recycling in the soil, very low use of chemical fertilizers, declining fallow times or continuous cropping, and soil erosion have all led to the depletion of basic cations and CEC on cultivated land compared to natural forest land.

Table 3. Exchangeable bases ( $\mathrm{Ca}, \mathrm{Mg}, \mathrm{K}$, and $\mathrm{Na}$ ), and $\mathrm{CEC}$ influenced by the land uses

\begin{tabular}{|c|c|c|c|c|c|c|c|}
\hline \multicolumn{5}{|c|}{ Exchangeable bases $\left(\mathrm{cmolc} \mathrm{kg}^{-1}\right)$} & \multirow[t]{2}{*}{ CEC } & \multirow{2}{*}{$\begin{array}{l}\text { Studied } \\
\text { Area }\end{array}$} & \multirow[t]{2}{*}{ Authors } \\
\hline Land uses & $\mathbf{C a}$ & Mg & $\mathbf{K}$ & $\mathrm{Na}$ & & & \\
\hline Forest land & $18.85 \mathrm{a}$ & $7.54 \mathrm{a}$ & $1.08 \mathrm{a}$ & $0.19 \mathrm{a}$ & $31.37 \mathrm{a}$ & Abobo Area, & me et \\
\hline Grazing land & $15.70 \mathrm{~b}$ & $6.08 \mathrm{~b}$ & $0.86 \mathrm{~b}$ & $0.15 b$ & $31.16 \mathrm{a}$ & Western & al., 2013) \\
\hline Cultivated land & $15.14 \mathrm{~b}$ & $5.89 \mathrm{~b}$ & $0.79 b$ & $0.11 \mathrm{c}$ & $26.31 \mathrm{~b}$ & Ethiopia & \\
\hline Forest land & 15.78 & 3.67 & $1.23 \mathrm{a}$ & 0.12 & $23.27 \mathrm{a}$ & South & Mamo \\
\hline Grazing land & 12.29 & 3.23 & $0.498 b$ & 0.14 & $22.18 \mathrm{a}$ & Gonder, & Yalew \\
\hline Cultivated land & 11.97 & 3.00 & $0.455 b$ & 0.10 & $21.44 \mathrm{~b}$ & $\begin{array}{l}\text { Agedit } \\
\text { Watershed }\end{array}$ & (2011) \\
\hline Forest land & $10.75 \mathrm{a}$ & $5.02 \mathrm{a}$ & $2.00 \mathrm{a}$ & $0.30 \mathrm{~b}$ & $28.17 \mathrm{a}$ & South Wello, & (Gebeyaw \\
\hline Grazing land & $3.26 \mathrm{c}$ & $0.88 \mathrm{~b}$ & $0.93 \mathrm{~b}$ & $0.34 \mathrm{a}$ & $17.17 \mathrm{~b}$ & Maybar Area & Tilahun \\
\hline Cultivated land & $3.96 \mathrm{~b}$ & $0.81 \mathrm{~b}$ & $0.85 \mathrm{~b}$ & $0.20 \mathrm{c}$ & $11.83 \mathrm{c}$ & & (2007) \\
\hline
\end{tabular}

3.2.4. Available Micronutrients

The term "micronutrients" refers to a number of elements that plants require in very small amounts. This term usually refers to elements found in plant tissues in concentrations of less than $100 \mathrm{mg} / \mathrm{kg}$ (Foth and Ellis, 1997). Zinc $(\mathrm{Zn})$, copper $(\mathrm{Cu})$, iron $(\mathrm{Fe})$, and manganese $(\mathrm{Mn})$ are the four essential micronutrients that exist as cations in soils, in contrast to boron and molybdenum (Mn). Parent material, soil texture, soil reaction, and soil OM are all factors that influence micronutrient availability (Brady and Weil, 2002). According to Teshome et al., (2013), land use has a considerable impact on the content of available micronutrients. For all forms of land use, the Mn 
and $\mathrm{Zn}$ concentrations were high, whereas the Fe value was medium. $\mathrm{Cu}$ content, on the other hand, was low in cultivated land and medium in forest and grazing land, respectively. Significantly, the highest micronutrient values were found in forest land soils, while the lowest values were found in cultivated land soils (Table 4). The availability of micronutrients was observed to increase when the CEC of soils increased, owing to the increased availability of exchange sites on soil colloids (M. Kumar and A.L. Babel, 2011). The authors also stated that increased organic matter improved micronutrient availability because (i) organic matter improves soil structure and aeration, (ii) organic matter protects micronutrients from oxidation and precipitation into unavailable forms, and (iii) organic matter supplies soluble chelating agents that increase the solubility of micronutrient contents. Similarly, land use has a considerable impact on the concentration of accessible micronutrients (Fe, Mn, $\mathrm{Zn}$, and $\mathrm{Cu}$ ), according to Gebeyew (2007). The highest concentrations of $\mathrm{Fe}, \mathrm{Mn}, \mathrm{Zn}$, and $\mathrm{Cu}$ were found on grazing ground, while the lowest concentrations of $\mathrm{Fe}, \mathrm{Zn}$, and $\mathrm{Cu}$ were found on cultivated land, and the lowest concentration of $\mathrm{Mn}(29.46 \mathrm{mg} / \mathrm{kg})$ was found on forest land (Table 4). The lowest available micronutrients under farmed land relative to other land use types may be due to crop harvest, OM degradation, and sheet and rill erosions, all of which have been exacerbated by continuous cultivation with extremely low input agricultural systems. Mamo (2011) also discovered that land use has a significant impact on the content of accessible micronutrients $(\mathrm{Fe}, \mathrm{Mn}, \mathrm{Zn}$, and $\mathrm{Cu}$ ). The highest concentrations of accessible $\mathrm{Fe}, \mathrm{Mn}, \mathrm{Zn}$, and $\mathrm{Cu}$ were found in grazing area, while the lowest concentrations were found in cultivated land (Table 4).

Table 4. Available micronutrients (Fe, $\mathrm{Mn}, \mathrm{Zn}$ and $\mathrm{Cu}$ ) influenced by different land use

\begin{tabular}{llllll}
\hline \multirow{2}{*}{ Land uses } & \multicolumn{2}{l}{ Available micronutrients $\left(\mathbf{m g ~ k g}^{-\mathbf{1}}\right)$} & & \multirow{2}{*}{ Authors } \\
\cline { 2 - 5 } & $\mathbf{F e}$ & $\mathbf{M n}$ & $\mathbf{Z n}$ & $\mathbf{C u}$ & \\
\hline Forest land & $30.92 \mathrm{a}$ & $42.18 \mathrm{a}$ & $4.22 \mathrm{a}$ & $4.34 \mathrm{a}$ & Teshome et \\
Cultivated land & $29.21 \mathrm{~b}$ & $40.54 \mathrm{~b}$ & $3.01 \mathrm{~b}$ & $2.68 \mathrm{~b}$ & al., 2013 \\
Grazing land & $28.82 \mathrm{c}$ & $29.75 \mathrm{c}$ & $2.53 \mathrm{~b}$ & $2.00 \mathrm{c}$ & \\
\hline Forest land & $20.55 \mathrm{~b}$ & $29.46 \mathrm{c}$ & $0.21 \mathrm{~b}$ & $0.87 \mathrm{~b}$ & Gebeyaw \\
Cultivated land & $29.35 \mathrm{a}$ & $32.18 \mathrm{a}$ & $0.89 \mathrm{a}$ & $1.86 \mathrm{a}$ & Tilahun, \\
Grazing land & $19.11 \mathrm{c}$ & $31.39 \mathrm{~b}$ & $0.15 \mathrm{~b}$ & $0.23 \mathrm{c}$ & $(2007)$ \\
\hline Forest land & $19.21 \mathrm{~b}$ & $26.23 \mathrm{a}$ & $0.20 \mathrm{~b}$ & $0.55 \mathrm{~b}$ & Mamo \\
Cultivated land & $27.53 \mathrm{a}$ & $30.20 \mathrm{a}$ & $0.80 \mathrm{a}$ & $1.12 \mathrm{a}$ & Yalew \\
Grazing land & $15.95 \mathrm{~b}$ & $21.10 \mathrm{~b}$ & $0.15 \mathrm{~b}$ & $0.24 \mathrm{~b}$ & $(2011)$ \\
\hline
\end{tabular}

\section{SUMMARY AND CONCLUSION}

Most developing countries' economies, like Ethiopia's, are built mostly on agricultural production (IFPRI, 2010). However, Ethiopian agriculture is under risk due to unwise use of land resources and land use changes. In Ethiopia, land use change such as conversion of natural forest to farming, open grazing, and homestead land are common. Such shifts in land use are prevalent, especially in the highlands, where population density is high and natural resources are directly impacted. In Ethiopia's highlands, massive deforestation and conversion to agricultural production, as well as continuous and intensive soil cultivation with extremely minimum inputs, have been performed. Due to population pressure, marginal lands and steep slopes have been cultivated.

The findings of many research show considerable changes in the quality attributes of soils in some parts of the country as a result of the loss or destruction of vegetative cover and frequent tillage, both of which lead to soil erosion and, as a result, deteriorating soil fertility. The immediate causes of land degradation, such as the decline in the use of fallow, the limited recycling of dung and crop residues to the soil, the limited use of external sources of plant nutrients, deforestation, and overgrazing, are obvious and widely acknowledged.

Different studies showed that soil physicochemical properties such as Particle size distribution (sand, silt, clay), Bulk density, Total porosity (\%), OC, C: $\mathrm{N}$ ratio, TN, pH, CEC Ava-P, and Ava (EB: $\mathrm{K}^{+}, \mathrm{Ca}^{2+}, \mathrm{and}^{\mathrm{Mg}^{2+}}$ ), Ava $\left(\mathrm{EX} ; \mathrm{Fe}^{2+}, \mathrm{Mn}^{2+}, \mathrm{Zn}^{2+}, \mathrm{Cu}^{2+}\right)$ were affected by different land use systems. When compared to the soil properties of the neighboring forest and grazing field soils, the quality of the soils under farmed lands revealed an overall trend in the direction of loss of fertility. Soil organic matter, which is the primary source of plant nutrients (such as N, S, and P) and helps to maintain soil fertility through mineralization and nutrient retention in low-input tropical farming systems, has seen significant decreases. According to the findings of the various studies, soil quality and health were relatively maintained under the forest, whereas the influence on most parameters was negative on the soils of cultivated land, indicating the need for intervention to optimize and sustain soil quality in the case of cultivated land. The management of soil organic matter (OM) should be given special attention because it is linked to a variety of physicochemical qualities.

Consequently, understanding the impact of agro-ecosystem transformation on agricultural soil quality and productivity, as well as identifying appropriate and sustainable agricultural soil and land management options, requires assessing land use-induced changes in soil physicochemical properties and their subsequent implications on soil fertility. 


\section{REFERENCE}

Achalu Chimdi, Heluf Gebrekidan, Kibebew Kibret and Abi Tadesse. 2012. Status of selected physicochemical properties of soils under different land use systems of Western Oromia, Ethiopia. Journal of Biodiversity and Environmental Sciences, 2(3): 57-71

Aluko, A.P. and Fagbenro, J.A. (2000). The role of tree species and land use systems in organic matter and nutrient availability in degraded Ultisol of Onne, Southeastern Nigeria. Annual Conference of Soil Science Society, Ibadan, Oyo State.

Berhanu Seyoum. 2016. Assessment of soil fertility status of Vertisols under selected three land uses in Girar Jarso District of North Shoa Zone, Oromia National Regional State, Ethiopia. Environmental System Research Journal, 5(18):1-16. doi: 10.1186/s40068-016-0069-y.

Bohn, H.L, B.L. McNeal and G.A. O'Connor, 2001. Soil chemistry, $3^{\text {rd }}$ Ed. John Wiley and Sons, Inc., New York. 307p.

Brady N.C. and Weil R.R. (2002). The nature and properties of soils, $13^{\text {th }}$ Ed. Prentice- Hall Inc., New Jersey, USA.

Chikezie, A., Eswaran, H., Asawalam, D.O. and Ano, A.O. (2009). Characterization of the benchmark soils of contrasting parent materials in Abia State, Southeastern Nigeria. Global Journal of Pure and Applied Sciences 16(1): 23-29.

Desta, B. 1983. Micrinutrient status of some Ethiopian soils. Institute of Agricultural Research, Addis Ababa.

Duff, B., P.E. Rasmussen and R.W. Smiley, 1995. Wheat/fallow systems in semi-arid regions of the Pacific, north-west America. pp. 85-109. In: Barnett, V. Payne, R. and Steiner, R. (Eds). Agricultural Sustainability: Economic, Environmental and Statistical Considerations. John Wiley and Sons, Inc., New York.

Elias, E. 2002. Farmers' perceptions of soil fertility change and management. SOS-Sahel and Institute for Sustainable Development, Addis Ababa, Ethiopia.

Eyayu Molla, Heluf Gebrekidan, Tekaliign Mamo and Mohammed Assen, 2009. Effects of land use change on selected soil properties in the Tera Gedam Catchment and adjacent agroecosystems, north-west Ethiopia, Ethiopian Journal of Natural Resources. 11(1): 3562.

Foth, H.D. and B.G. Ellis., 1997. Soil fertility, 2nd Ed. Lewis CRC Press LLC., USA. 290p.

Foth, H.D., 1990. Fundamentals of soil science, 8th Ed. John Wiley and Sons, Inc., New York, USA. 360p.

Gebeyaw Tilahun. 2007. Soil fertility status as influenced by different land uses in Maybar areas of South Wello Zone, North Ethiopia. MSc Thesis, Haramaya University, Haramaya, Ethiopia. Pp. 30-47.

Genxu, W., Haiyan, M., Ju, Q. and Juan, C. (2004). Impact of land use changes on soil carbon, nitrogen and phosphorus and water pollution in an arid region of northwest China. Soil use and Management 20: 3239.

Grace, P.R., J.M. Oades, H. Keith and T.W. Hancock, 1995. Trends in wheat yields and soil organic carbon in the permanent rotation trial at the Waite Agricultural Research Institute, South Australia. Australian Journal of Experimental Agriculture. 35: 857-864.

Gupta, P.K., 2004. Soil, plant, water and fertilizer analysis. Shyam Printing Press, Agrobios,India. 438p.

Habtamu, A., Heluf Gebrekidan., Bobe Bedadi and Enyew, A. 2014. Fertility status of soils under different land uses at Wujiraba watershed, North-Western Highlands of Ethiopia. Agriculture, Forestry and Fisheries, 3(5):410-419. doi: 10.11648/j.aff.20140305.24.

Hazelton, P. and Murphy, B. 2007. Interpreting soil test results: What do all the numbers mean? 2nd Edition. CSIRO Publishing. p.152.

Hillel, D., 1980. Fundamentals of soil physics. Harcourt Brace Jovanivich Publisher, Academic Press, Inc. San Diego. 413p.

Hurni, H., 1988. Degradation and conservation of the resources in the Ethiopian highlands. Mountain Research and Development. 8 (2/3): 123-130.

IFPRI (International Food Policy Research Institute). 2010. Fertilizer and Soil Fertility Potential in Ethiopia: Constraints and opportunities for enhancing the system. Washington DC, 42. 3(12):187-200.

Jobira Defera, 2018. Assessment of physicochemical properties of soil under different land use types at wuye gose subwatershed, north shoa zone of oromia region, Ethiopia. MSc Thesis, Haramaya University, Ethiopia.

Kedir Abate, Muktar Mohammed and Kibebew Kibret. 2016. Soil Fertility Assessment and Mapping of Spatial Variability at Amareganda-Abajarso Sub-Watershed, North Eastern Ethiopia. East African Journal of Sciences, 10 (1): 1-14.

Kippe, T. 2002. Five thousand years of sustainability: A case study on dedeo land use, southern Ethiopia. Doctorial Thesis, Treemail Publishers, Heelsum, p. 295.

Lechisa Takele, Achalu Chimdi and Alemayeh Abebaw, 2014. Impacts of Land use on Selected Physicochemical Properties of Soils of Gindeberet Area, Western Oromia, Ethiopia. Science, Technology and Arts Research Journal Sci. Technol. Arts Res. J., Oct-Dec 2014, 3(4): 36-41.

M. Kumar and A.L. Babel. "Available micronutrient status and their relationship with soil properties of 
Jhunjhunu Tehsil, District Jhunjhunu, Rajasthan, India”. Journal of Agricultural Science. 3(2): 97-106, 2011.

Mamo Yalew, 2011. Influence of land use systems on selected soil physical and chemical properties at agedit watershed, south gondar zone, amhara regional state. MSc Thesis, Haramaya University, Ethiopia.

Mengel, K. and E.A. Kirkby, 1987. Principles of plant nutrition Panima Pub. Corporation, New Delhi, Bangalore, India. $687 \mathrm{p}$.

Mesfin Abebe, 1998. Nature and management of Ethiopian soils. Alemaya University of Agriculture, Ethiopia. $272 \mathrm{p}$.

Muche Meseret, Kokeb Addis and Molla Eyayu. 2015. Assessing the Physicochemical Properties of Soil under Different Land Use Types. Journal of Environment, Analytical Toxicology, 5: 309. doi:10.4172/21610525.1000309 .

Rao, K.S. and R. Pant, 2001. Land use dynamics and landscape change pattern in a typical micro watershed in the mid elevation zone of central Himalaya, India. Agriculture, Ecosystems and Environment 86: 113-123.

Saikh, H., C. Varadachari and K. Ghosh, 1998a. Changes in carbon, nitrogen and phosphorus levels due to deforestation and cultivation. A Case Study in Simplipal National Park, India. Plant and Soil. 198: 137-145.

Sanchez, P.A., 1976. Properties and management of soils in the tropics. John Wiley and Sons, Inc., New York, USA. 618 p.

Solomon, D., J. Lehmann, M. Tekalign, F. Fritzsche and W. Zech, 2002. Phosphorus forms and dynamics as influenced by land use changes in the sub-humid Ethiopian highlands. Geoderma 105: 21-48.

Tekalign Mamo, I. Haque, and C.S. Kamara, 1988. Phosphorus status of Ethiopian Vertisols: Management of Vertisols in Sub-Saharan Africa. pp. 232-252. Proceeding of the Conference Held at International Livestock Centre for Africa (ILCA), 31 August4September 1987.

Tekalign Tadese. 1991. Soil, plant, water, fertilizer, animal manure and compost analysis. Working Document No. 13. International Livestock Research Center for Africa, Addis Ababa, Ethiopia.

Tekle, K. and Hedlund, L. 2000. Land covers change between 1958 and 1986 in Kalu district, southern Wello, Ethiopia. Material Research Development, 20:2-51.

Teshome Yitbarek, Heluf Gebrekidan, Kibebew Kibret, Sheleme Beyene, 2013. Impacts of Land Use on Selected Physicochemical Properties of Soils of Abobo Area, Western Ethiopia. Agriculture, Forestry and Fisheries. Vol. 2, No. 5, 2013,pp. 177-183. doi: 10.11648/j.aff.20130205.11

Turner, B.L, D. Skole and S. Sanderson, 1995. Land-use and land-cover change: Science/Research plan. IGBP Report 35 / HDP Report 7. IGBP Press Stockholm and Geneva. 165p.

Wakene Negassa and Heluf Gebrekidan, 2003. Influence of land management on morphological, physical and chemical properties of some soils of Bako, Western Ethiopia. Agropedology, 13(2): 1-9.

Wakene, N. (2001). Assessment of important physicochemical properties of Dystric Nitosols under different management systems in Bako area, western Ethiopia. M.Sc. Thesis Submitted to School of Graduate Studies, Alemaya University, Ethiopia.

Wasihun Mengiste, 2015. Evaluation of the effect of land use types on Selected soil physico-chemical properties in Itang-ker area of Gambella regional state of Ethiopia. Haramaya University, Haramaya.

Whitebread, A.M., R.B.D. Lofroy and G.J. Blair, 1998. A survey of impact of cropping on soil physical and chemical properties in Northeastern New South Wales. Aust. J. Soil Res.

Yifru, A. and Taye, B. (2011). Effects of land use on soil organic carbon and nitrogen in soils of bale, southeastern Ethiopia. Journal of Tropical and Subtropical Agro Ecosystems 14: 229-235. 